\title{
Evaluation of the antioxidant activity of fruit extracts of indigenous medicinal plant, Zizyphus xylopyrus (Retz.) Willd
}

\section{Mohammad Hashim Mansoori ${ }^{1,2}$, M.K. Gupta², Vijay Mishra ${ }^{3 *}$, Nishika Yadav ${ }^{3}$, Manish Vyas ${ }^{3}$}

\author{
${ }^{1}$ Department of Pharmacy, Adina Institute of Pharmaceutical Sciences, Sagar, Madhya Pradesh, India, \\ ${ }^{2}$ Department of Pharmacy, Oriental University, Indore, Madhya Pradesh, India, ${ }^{3}$ School of Pharmaceutical \\ Sciences, Lovely Professional University, Phagwara, Punjab, India
}

\begin{abstract}
Aim: This study aims to investigate the antioxidant activity of fruit extracts of an indigenous medicinal plant, Zizyphus xylopyrus (Retz.) Willd. Materials and Methods: The coarsely powdered fruit of Z. xylopyrus Willd. was successfully extracted first with petroleum ether and chloroform, followed by ethyl acetate and at last ethanol. The total flavonoids content (TFC), total phenolic content (TPC), and total tannin content (TTC) were estimated using quercetin and tannic acid equivalents as standard. The antioxidant activity of different extracts was determined by different standard in vitro methods including. Results: Among all extracts, ethyl acetate extract (ZXEAE) possessed potent antioxidant activity, namely hydroxyl radical $\left(\mathrm{OH}^{\circ}\right)$ scavenging assay $\left(\mathrm{IC}_{50} 128.1 \pm 0.63 \mu \mathrm{g} / \mathrm{mL}\right.$ ), 2,2-diphenyl-1-picrylhydrazyl (DPPH) radical (DPPH ${ }^{\circ}$ ) scavenging assay $\left(\mathrm{IC}_{50} 101.2\right.$ $\pm 1.75 \mu \mathrm{g} / \mathrm{mL}$ ), nitric oxide radical $\left(\mathrm{NO}^{\circ}\right)$ scavenging assay $\left(\mathrm{IC}_{50} 122.5 \pm 2.04 \mu \mathrm{g} / \mathrm{mL}\right)$, superoxide radical $\left(\mathrm{O}_{2}^{-}\right)$ scavenging activity assay $\left(\mathrm{IC}_{50} 64.1 \pm 1.24 \mu \mathrm{g} / \mathrm{mL}\right)$, and inhibition of lipid peroxidation $(98.6 \pm 2.05 \mu \mathrm{g} / \mathrm{mL})$. Study results suggested that antioxidant activity of ZXEAE might be due to presence of polyphenols, namely TFC $(31.23 \pm 0.39$ quercetin equivalent $[\mathrm{QE}] \mathrm{mg} / \mathrm{g}$ extract), TPC $(198.14 \pm 0.69$ gallic acid equivalent $[\mathrm{GAE}] \mathrm{mg} / \mathrm{g}$ extract), and TTC (18.38 $\pm 1.79 \mathrm{GAE} \mathrm{mg} / \mathrm{g}$ extract). Conclusion: The present study demonstrated the presence of flavonoids in Z. xylopyrus fruits showing marked antioxidant activity, which can be used for establishing the hepatoprotective potential of $Z$. xylopyrus.
\end{abstract}

Key words: Antioxidant, flavonoids, free radicals, Zizyphus xylopyrus

\section{INTRODUCTION}

$\mathrm{T}$ The liver is a vital organ estimated to have over 500 functions, responsible for the synthesis of a variety of proteins such as albumin, $\alpha 1$-antitrypsin, very low-density lipoprotein, coagulation factors, insulin-like growth factor, and thrombopoietin. Lipophilic substances (e.g., drugs) are metabolized by hepatocyte enzymes in the liver to either less/ non-toxic substances (detoxification) or more 13 toxic substances (toxification). Failure of these metabolic functions represents the basic pathophysiology of all forms of liver disease. Hepatocytes represent $60 \%$ of liver cells and are responsible for most of its synthetic and metabolic activities..$^{[1,2]}$

Herbal plants have high percentage of phenolic compounds, which act as antioxidant compounds. Antioxidant compounds have redox properties which show its action by neutralizing the free radicles and decompose peroxides. ${ }^{[3,4]}$ The inadequacy of orthodox drugs in the management of liver disease is apparent in the continuing premature deaths and disabilities resulting from these diseases. Traditional medicine has over time offered, in the form of medicinal plants, an alternative to this malady. Quite a number of plants are used in altered parts of the world for the management of liver diseases. Among such plants, Zizyphus xylopyrus (Retz.) Willd. (family: Rhamnaceae) as folk medicine with distinct medicinal values have created

\section{Address for correspondence: \\ Dr. Vijay Mishra, School of Pharmaceutical Sciences, Lovely Professional University, Phagwara - 144411, Punjab, India.E-mail: vijaymishra2@gmail.com}

Received: $27-10-2018$

Revised: 21-11-2018

Accepted: $30-11-2018$ 
curiosity among researchers worldwide for their various important biological activities. Z. xylopyrus possesses a number of bioactivities. ${ }^{[5-7]}$ The study aims to execute the biological active constituents existing in different extracts of $Z$. xylopyrus fruits showing potent antioxidant activity, responsible for the hepatoprotection in contradiction of oxidative stress persuades liver damage.

\section{MATERIALS AND METHODS}

\section{Chemicals and Reagents}

Vitamin C, quercetin, gallic acid, thiobarbituric acid (TBA), trichloroacetic acid, sodium nitroprusside, nitro blue tetrazolium (NBT), hydroxylamine hydrochloride, streptomycin, and penicillin were purchased from Sigma-Aldrich, Mumbai. The carbon tetrachloride, 1-napthylethylenediamine dihydrochloride, sulfanilamide, orthophosphoric acid, and Folin-Ciocalteu reagents were purchased from SD Fines Chemicals Pvt., Ltd., Mumbai. 2,2-diphenyl-1-picrylhydrazyl (DPPH) and ethylenediaminetetraacetic acid (EDTA) were purchased from Bioworld, Mumbai, and Hi-Media, Bengaluru, respectively. All other solvents and chemicals of analytical grade used in this study were obtained from local supplier.

\section{Collection and Authentication of Plant Material}

The fruits of Z. xylopyrus (Retz.) Willd. (ZX) collected from the plants grown in Sagar, Madhya Pradesh, India, were validated by Dr. P. K. Tiwari, Department of Botany, Dr. H. S. Gour Central University, Sagar, Madhya Pradesh, India. The specimen of $Z$. xylopyrus (Retz.) Willd. with Bot/H/02/49/03 Herbarium number was deposited in botany department of university for upcoming reference. The plant constituents were initially washed by water followed by drying in shade and then coarsely powdered from grinder.

\section{EXPERIMENTAL ANIMALS}

For the present investigation, Swiss albino rats of either sex with weight of 180-240 g were acquired from the College of Veterinary Sciences and Animal Husbandry, Mhow, Madhya Pradesh, India. The animals were made familiarize for the duration of 2 weeks from the beginning of the experiment and housed in standard laboratory surroundings, that is, $45-65 \%$ of relative humidity, $25 \pm 2^{\circ} \mathrm{C}$ of temperature, and $12 \mathrm{~h}$ dark and $12 \mathrm{~h} \mathrm{light} \mathrm{cycle.} \mathrm{Animals} \mathrm{were} \mathrm{fed} \mathrm{by} \mathrm{standard}$ laboratory animal feed and water ad libitum during the experiment. The protocol for experimental work on animals was approved by the Institution Animal Ethical Committee (IAECNo.1546/PO/E/S/11/CPCSEA).

\section{Extraction of Plant Materials}

In a Soxhlet apparatus, the coarse powder of fruits was closely packed and successive extraction was carried out first with petroleum ether at $40-60^{\circ} \mathrm{C}$ and then with chloroform, followed by ethyl acetate and at last ethanol. Maceration for $48 \mathrm{~h}$ in distilled water was carried out with the leftover marc and then filtered. From thimble of the apparatus, some drops of extractive were collected and evaporated. The absence of residue confirmed completion of the extraction process. This ensures that no solvents remain; the marc was dried in air before using next solvent for extraction. Rotary evaporator set at $40 \pm 2{ }^{\circ} \mathrm{C}$ was used for vacuum drying the collected filtrates. The different ZX extracts used in the present study are - petroleum ether extract (ZXPEE), chloroform extract (ZXCHE), ethyl acetate extract (ZXEAE), ethanolic extract (ZXEE), and aqueous extract (ZXAQE).

\section{DETERMINATION OF PHYTOCONSTITUENTS}

- Preliminary phytochemical screening

The preliminary phytochemical analysis outcomes of ZX extracts determined that ZXEAE contained tannins and flavonoids. ZXEE comprises alkaloids, carbohydrate, tannins, and flavonoids; ZXCHE contains phytosterols and triterpenoids, whereas ZXAQE consists of glycoside and carbohydrate. Amino acid and proteins were absent in entire extracts although fats and fixed oil were present only in ZXPEE of ZX extract.

- Total flavonoid content (TFC)

The reaction between aluminum trichloride $\left(\mathrm{AlCl}_{3}\right)$ and flavonoids produces a red-colored compound, their intensity is measured to determine the TFC. ${ }^{[8]}$

- Total phenolic content (TPC) and Total tannin content (TTC)

Precipitation of tannins using gelatin was carried out for the identification of TTC, while Folin-Ciocalteu method was utilized for the identification of TPC..$^{[9]}$

\section{Determination of Antioxidant Activity}

- Reducing power assay

Antioxidants are potent reductants. Their presence would result in $\mathrm{Fe}^{3+}$ to $\mathrm{Fe}^{2+}$ reduction due to electron donation. This serves as an indication for antioxidant activity. Chromophore absorbance measured at wavelength of $700 \mathrm{~nm}$ to determine the reducing power of extracts. ${ }^{[10]}$

- DPPH radical scavenging assay

This scavenging assay is used to understand the extracts' antiradical activities and to determine the presence of flavonoids and phenolics. ${ }^{[11]}$ Reaction between $\mathrm{DPPH}^{\circ}$ radical and proton donor leads to the formation of complex of yellow color. The intensity of this color is used to determine the $\mathrm{DPPH}^{\circ}$ radical scavenging 
activity. ${ }^{[8]}$ The $\mathrm{DPPH}^{\circ}$ radical scavenging activity was determined by Equation 1.

Scavenging activity $(\%)=\left(\frac{A_{o}-A_{t}}{A_{o}}\right) \times 100$

Where, $\mathrm{A}_{0}=$ Control absorbance and $\mathrm{A}_{\mathrm{t}}=$ Sample absorbance

- $\mathrm{OH}^{\circ}$ scavenging assay

$\mathrm{OH}^{\circ}$ can be produced using Fenton reaction in occurrence of the reduced transition metals $\left(\mathrm{Fe}^{2+)}\right.$ and $\mathrm{H}_{2} \mathrm{O}_{2}$, known as the best reactive system amid all dioxygen reduced forms and thought to begin in vivo the cell injury. ${ }^{[12]}$

- $\quad$ Nitric oxide $\left(\mathrm{NO}^{\circ}\right)$ radical scavenging assay Griess reagent has the ability to inhibit $\mathrm{NO}^{\circ}$ radical. The radical generated as of sodium nitroprusside solution in the phosphate buffer saline. The ability of Griess reagent to inhibit $\mathrm{NO}^{\circ}$ radical was analyzed at $546 \mathrm{~nm} .{ }^{[13]}$ The $\mathrm{NO}^{\circ}$ radical scavenging activity was determined by Eq. 1

- $\quad$ Superoxide $\left(\mathrm{O}_{2}^{-}\right)$radical scavenging assay

NBT reagent method was used for the estimation of $\mathrm{O}_{2}$ radical scavenging action of extracts. In the presence of NBT, autoxidation of hydroxylamine hydrochloride results in the formation of $\mathrm{O}_{2}^{-}$. The radical is then reduced to nitrite. In the presence of EDTA, the nitrite ion produces a colored complex, intensity measured at $560 \mathrm{~nm} \cdot{ }^{[14]}$ The $\mathrm{O}_{2}{ }^{-}$radical scavenging ability was determined by Eq. 1 .

- Inhibition of lipid peroxidation (LPO) in rat liver homogenate

When malondialdehyde, secondary end product of $\mathrm{Fe}^{2+}$ induced polyunsaturated fatty acids oxidation, reacts from two molecules of 2-TBA, it leads to the formation of pinkish-red-colored chromogen. The intensity of this chromogen is measured to determine LPO inhibition activity of the extracts. A decrease in LPO is indicated by a decrease in absorbance. ${ }^{[15,16]}$ Percent inhibition of LPO was determined by Eq. 1 .

\section{Statistical Analysis}

The results of the studies were reported as mean \pm SEM $(n=3)$. Total variation in a set of data was estimated by one-way analysis of variance, followed by Dunnett's test for determining statistical significance. The values $<0.05$ were considered as statistically significant.

\section{RESULTS AND DISCUSSION}

\section{Determination of Phytoconstituents by Preliminary Phytochemical Screening}

The preliminary phytochemical study outcome of extracts of ZX presented that ZXEAE comprises tannins and flavonoids;
ZXEE has carbohydrate, glycosides, tannins, flavonoids, and alkaloids; ZXCHE comprises triterpenoids and phytosterols although ZXAQE has glycoside and carbohydrate. Amino acids and proteins are lacking in all extracts, whereas fixed oil and fats were present only in ZXPEE. Table 1 represents the results of preliminary phytochemical screening.

\section{Estimation of TPC, TFC, and TTC}

TPC in different extracts of ZX was estimated through measure the blue color intensity formed at $\lambda_{\text {max }} 765 \mathrm{~nm}$, whereas extracts TTC was estimated by deducting phenolics non-tannin from TPC. Their outcome was stated in comparison to gallic acid equivalent (GAE), mg of GAE/g of extract GAE determined by regression equation $\mathrm{y}=0.0588 \mathrm{x}+0.0025$ and $r^{2}=0.9994$, where $\mathrm{x}$ is absorbance and $\mathrm{y}$ is GAE. Different ZX extracts have different TPC, TFC, and TTC levels [Figure 1]. The maximum TPC was obtained in ZXEAE $(198.14 \pm 0.69 \mathrm{mg}$ GAE/g of extract), followed by ZXEE (121.12 \pm 0.74$), \mathrm{ZXCHE}$ (28.24 \pm 0.28$),$ ZXAQE $(21.24 \pm 0.35)$, and ZXPEE (18.51 $\pm 0.31)$. The maximum TTC was obtained in ZXEE (42.52 $\pm 0.98 \mathrm{mg}$ GAE $/ \mathrm{g}$ of extract), followed by ZXAQE (19.12 $\pm 1.76), \operatorname{ZXEAE}(18.38 \pm 1.79), \mathrm{ZXCHE}(9.51 \pm 1.39)$, and ZXPEE (7.42 $\pm 0.89 \mathrm{mg} \mathrm{GAE} / \mathrm{g}$ of extract). TFC in the plant extracts studied by determining red color intensity developed due to reaction between $\mathrm{AlCl}_{3}$ and flavonoids at $420 \mathrm{~nm} \lambda_{\text {max }}$. TFC was stated in comparison to the quercetin equivalent $\mathrm{mg}$ of $\mathrm{QE} / \mathrm{g}$ of extract, estimated by means of regression equation $\mathrm{y}=0.0199 \mathrm{x}+0.0046, r^{2}=0.9952$, where $\mathrm{y}$ is $\mathrm{QE}$ and $\mathrm{x}$ is absorbance. Maximum flavonoid content was obtained in ZXEAE (31.23 $\pm 0.39 \mathrm{mg}$ QE/g of extract) followed by ZXEE $(11.07 \pm 1.97), \mathrm{ZXCHE}(4.52 \pm 0.65)$, ZXPEE (3.18 \pm 0.94$)$, and ZXAQE $(3.10 \pm 0.99 \mathrm{mg} \mathrm{QE} / \mathrm{g}$ of extract).

\section{ESTIMATION OF ANTIOXIDANT ACTIVITY}

\section{Ferric Reducing Antioxidant Power Assay}

In this study, the reducing ability of various extracts of ZX observed at various concentrations $(20-200 \mu \mathrm{g} / \mathrm{mL})$

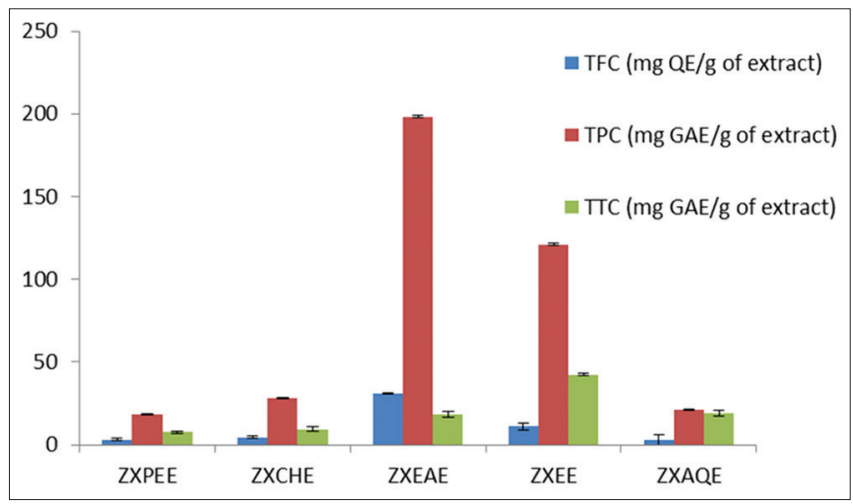

Figure 1: Quantity of total phenolic content, total tannin content, and total flavonoids content extant in ZX extracts 


\begin{tabular}{|c|c|c|c|c|c|}
\hline Tests & ZXPEE & ZXCHE & ZXEAE & ZXEE & ZXAQE \\
\hline \multicolumn{6}{|l|}{ Tests for carbohydrate } \\
\hline Benedict's test & - & - & - & - & - \\
\hline Molisch's test & - & - & - & + & + \\
\hline Fehling's test & - & - & - & - & + \\
\hline \multicolumn{6}{|l|}{ Tests for alkaloids } \\
\hline Dragendorff's test & - & - & - & + & - \\
\hline Mayer's test & - & - & - & + & - \\
\hline Hager's test & - & - & - & + & - \\
\hline Wagner's test & - & - & - & + & - \\
\hline \multicolumn{6}{|l|}{ Tests for glycosides } \\
\hline Keller-Killiani test & - & - & + & - & - \\
\hline Legal's test & - & - & - & + & - \\
\hline Foam test & - & - & - & - & + \\
\hline Modified Borntrager's test & - & - & - & - & - \\
\hline \multicolumn{6}{|l|}{ Tests for flavonoids } \\
\hline Shinoda's test & - & - & + & + & - \\
\hline Alkaline reagent test & - & - & + & + & - \\
\hline \multicolumn{6}{|c|}{ Tests for triterpenoids and phytosterols } \\
\hline Liebermann's test & - & + & - & - & + \\
\hline Salkowski test & - & - & - & - & + \\
\hline Liebermann's-Burchard test & + & + & - & - & + \\
\hline \multicolumn{6}{|l|}{ Tests for amino acids and protein } \\
\hline Ninhydrin test & - & - & - & - & - \\
\hline Millon's test & - & - & - & - & - \\
\hline \multicolumn{6}{|l|}{ Tests for tannins } \\
\hline Lead acetate test & - & - & + & + & - \\
\hline Gelatin test & - & - & + & + & - \\
\hline Ferric chloride test & - & - & + & + & - \\
\hline \multicolumn{6}{|l|}{ Test for fat and fixed oils } \\
\hline Saponification test & + & - & - & - & - \\
\hline Filter paper test & + & - & - & - & - \\
\hline
\end{tabular}

ZXPEE: Petroleum ether extract, ZXCHE: Chloroform extract, ZXEAE: Ethyl acetate extract, ZXEE: Ethanolic extract, ZXAQE: Aqueous extract, where $(+)$ represents the presence and (-) represents the absence

[Figure 2]. The increase in absorbance further shows reducing power of extract, as a major indicator of antioxidant action potential. ${ }^{[17]}$ The numerous extracts reducing power of ZX were obtained in given order - Vitamin $C>$ ZXEAE $>$ ZXEE $>$ ZXPEE $>$ ZXCHE $>$ ZXAQE.

\section{$\mathrm{OH}^{\circ}$ SCAVENGING ASSAY}

Various extracts exhibited different and scavenging dosedependent activity in tested limit of concentration. Further than the tested extracts, highest scavenging action detected with ZXEAE (Figure 3). $\mathrm{IC}_{50}$ of Vitamin $\mathrm{C}$ was obtained as $8.9 \pm$ $0.44 \mu \mathrm{g} / \mathrm{mL}$. The manner of scavenging action $\left(\mathrm{IC}_{50}\right)$ of Vitamin
$\mathrm{C}$ and extracts was resulted as follows: $8.9 \pm 0.44 \mu \mathrm{g} / \mathrm{mL}$ of Vitamin C> $119.5 \pm 0.51 \mu \mathrm{g} / \mathrm{mL}$ ZXEE $>128.1 \pm 0.63 \mu \mathrm{g} / \mathrm{mL}$ ZXEAE $>197.4 \pm 0.59 \mu \mathrm{g} / \mathrm{mL}$ ZXCHE $>243.6 \pm 0.72 \mu \mathrm{g} / \mathrm{mL}$ ZXAQE $>315.2 \pm 0.49 \mu \mathrm{g} / \mathrm{mL}$ ZXPEE. IC $_{50}$ of ZXEAE found 14.39 times lesser in contrast to Vitamin C. At $200 \mu \mathrm{g} / \mathrm{mL}$ of concentration, ZXEE and ZXEAE displayed $49.3 \%$ and $48.5 \% \mathrm{OH}^{\circ}$ radical scavenging action, respectively.

\section{DPPH RADICAL SCAVENGING ASSAY}

DPPH is free radical (stable) with extreme absorbance at wavelength of $517 \mathrm{~nm}$. It freely undergoes scavenging through an antioxidant and converted to 1 , 
1-diphenyl-2-picrylhydrazine. The discoloration degree shows the potential of scavenging activity of antioxidant substance. ${ }^{[12]}$ It had been broadly used to examine the compounds ability like hydrogen donors or free-radical scavengers and further in evaluation of activity of antioxidant present in plant extracts. In this study, capacity of $\mathrm{DPPH}^{\circ}$ radical scavenging activity of various extracts was observed at various concentrations $(10-200 \mu \mathrm{g} / \mathrm{mL})$. Extracts concentration was essential to reduce the DPPH initial concentration to $50 \%\left(\mathrm{IC}_{50}\right)$ below definite experimental situation was measured and outcome is expressed as mean \pm $\mathrm{SEM}$. Lesser $\mathrm{IC}_{50}$ value shows more antioxidant action.

Several extracts exhibited different and scavenging activitydependent dose in tested concentration range. Rest of the tested extracts, highest scavenging action was perceived by ZXEAE [Figure 4]. IC $_{50}$ of Vitamin $\mathrm{C}$ obtained to be $8.4 \pm$ $0.41 \mu \mathrm{g} / \mathrm{mL}$. Therefore, command of scavenging activities $\left(\mathrm{IC}_{50}\right)$ of plant extracts and Vitamin $\mathrm{C}$ resulted as Vitamin $\mathrm{C}$ $(8.4 \mu \mathrm{g} / \mathrm{mL})>$ ZXEAE $(101.2 \pm 1.75 \mu \mathrm{g} / \mathrm{mL})>$ ZXEE $(118.2$ $\pm 1.27 \mu \mathrm{g} / \mathrm{mL})>Z X X Q E(248.1 \pm 2.02 \mu \mathrm{g} / \mathrm{mL})>Z X C H E$ $(287.1 \pm 1.51 \mu \mathrm{g} / \mathrm{mL})>Z X P E E(332.2 \pm 2.06 \mu \mathrm{g} / \mathrm{mL}) . \mathrm{IC}_{50}$ of ZXEAE was obtained 12.05 times lesser as compared to Vitamin C. At $200 \mu \mathrm{g} / \mathrm{mL}$ concentration, ZXEE and ZXEAE indicated $56.1 \%$ and $68.3 \%$ DPPH radical scavenging property, respectively.

\section{$\mathrm{NO}^{\circ}$ radical scavenging assay}

The percentage of radical scavenging ability of the standard Vitamin $\mathrm{C}$ and ZX extracts contrary to radical of $\mathrm{NO}^{\circ}$ was improved in a dose $(10-200 \mu \mathrm{g} / \mathrm{mL})$-dependent mode. Outside the ZX tested extracts, highest scavenging property was detected with ZXEAE [Figure 5]. $\mathrm{IC}_{50}$ of Vitamin C was observed as $22.1 \pm 0.51 \mu \mathrm{g} / \mathrm{mL}$ and the manner of scavenging action $\left(\mathrm{IC}_{50}\right)$ of Vitamin $\mathrm{C}$ and extracts was resulted as follows: $22.1 \pm 0.51 \mu \mathrm{g} / \mathrm{mL}$ of Vitamin $\mathrm{C}>122.5 \pm 2.04 \mu \mathrm{g} /$ $\mathrm{mL}$ of ZXEAE $>138.3 \pm 0.79 \mu \mathrm{g} / \mathrm{mL}$ of ZXEE $>263.3 \pm$ $1.29 \mu \mathrm{g} / \mathrm{mL}$ of $\mathrm{ZXAQE}>398.3 \pm 1.63 \mu \mathrm{g} / \mathrm{mL}$ of ZXCHE> $418.3 \pm 1.84 \mu \mathrm{g} / \mathrm{mL}$ of ZXPEE. IC $_{50}$ of ZXEAE was found as 5.54 times lesser than Vitamin $C$ further at $200 \mu \mathrm{g} / \mathrm{mL}$ of concentration, the ZXEE and ZXEAE indicated 51.2\% and $57.1 \%$ of $\mathrm{NO}^{\circ}$ radical scavenging action, respectively.

\section{$\mathrm{O}_{2}-$ radical activity assay}

Various ZX extracts showed scavenging activity dose dependent on $\mathrm{O}_{2}^{-}$radical. Outside the tested extracts, highest scavenging action was detected with ZXEAE [Figure 6]. $\mathrm{IC}_{50}$ of Vitamin $\mathrm{C}$ was resulted as $29.1 \pm 0.39 \mu \mathrm{g} / \mathrm{mL}$. The scavenging activity $\left(\mathrm{IC}_{50}\right)$ of Vitamin $\mathrm{C}$ and extracts was as follows: $29.1 \pm 0.39 \mu \mathrm{g} / \mathrm{mL}$ of Vitamin $\mathrm{C}>64.1 \pm$ $1.24 \mu \mathrm{g} / \mathrm{mL}$ of ZXEAE $>107.1 \pm 2.09 \mu \mathrm{g} / \mathrm{mL}$ of ZXEE $>257.2 \pm 2.41 \mu \mathrm{g} / \mathrm{mL}$ of ZXAQE $>333.5 \pm 1.96 \mu \mathrm{g} / \mathrm{mL}$ of ZXCHE $>351.2 \pm 2.55 \mu \mathrm{g} / \mathrm{mL}$ of ZXPEE. ZXEAE $\mathrm{IC}_{50}$ is 2.20 times lesser as compared with Vitamin C. At $200 \mu \mathrm{g} / \mathrm{mL}$

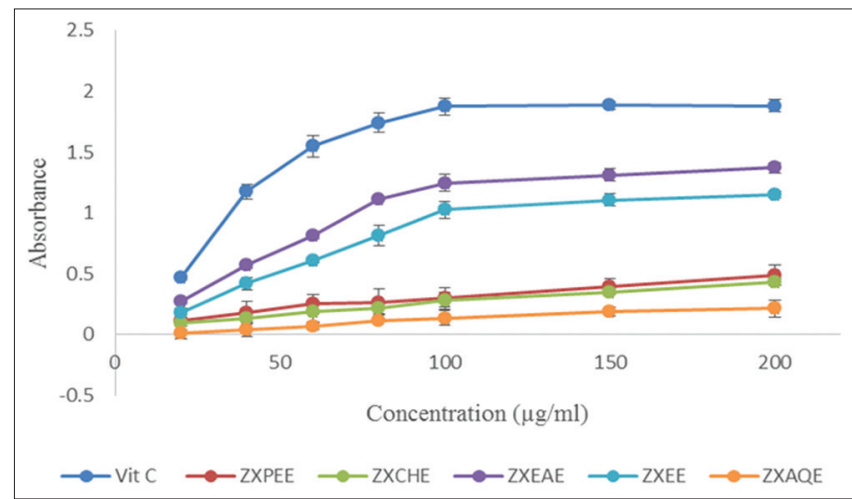

Figure 2: Reducing power of several extracts of ZX. The values are represented as mean $\pm \operatorname{SEM}(n=3)$

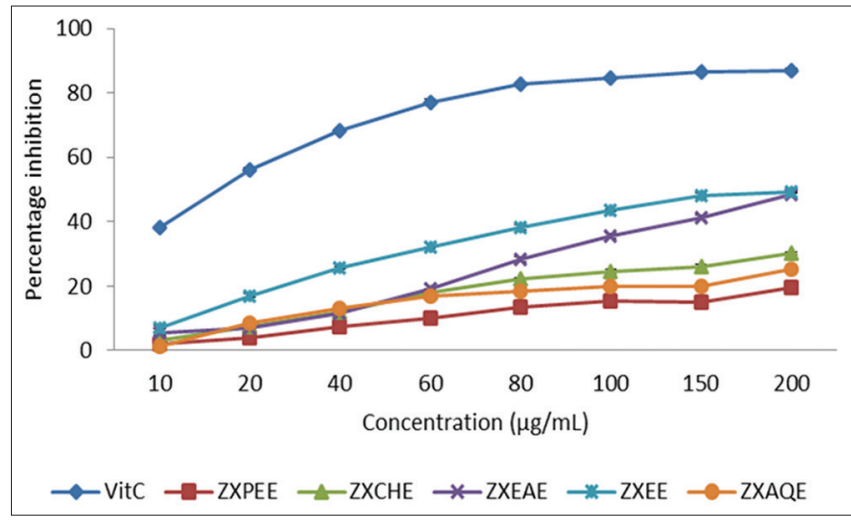

Figure 3: Percent inhibition by ZX extracts in hydroxyl radical scavenging assay. The values are represented as mean \pm $\operatorname{SEM}(n=3)$

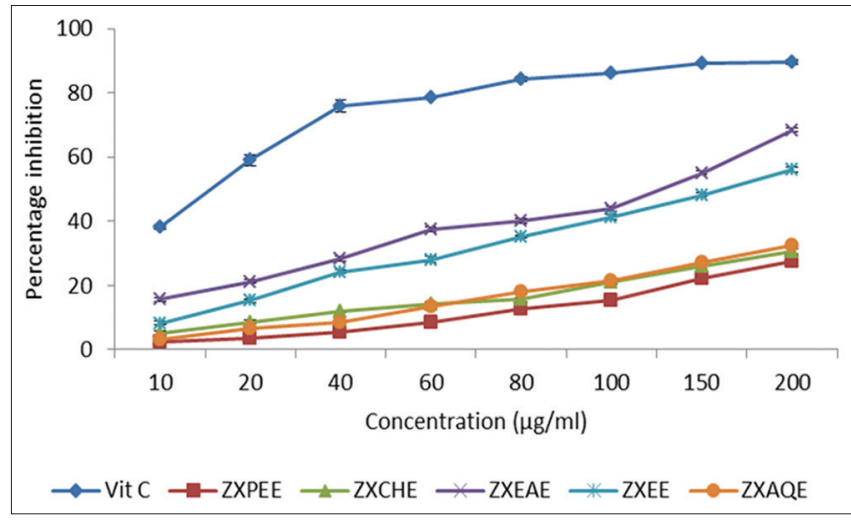

Figure 4: Percent inhibition by ZX extracts in 2,2-diphenyl1-picrylhydrazyl radical scavenging assay. The values are represented as mean \pm SEM $(n=3)$

concentration, ZXEE and ZXEAE presented $67.5 \%$ and $77.1 \% \mathrm{O}_{2}^{-}$radical scavenging activity, respectively.

\section{Inhibition of LPO Assay}

The capacity of LPO inhibition of various extracts of ZX was inspected at numerous concentrations as $20-150 \mu \mathrm{g} / \mathrm{mL}$, the value of $\mathrm{IC}_{50}$ of different extracts under definite experimental 


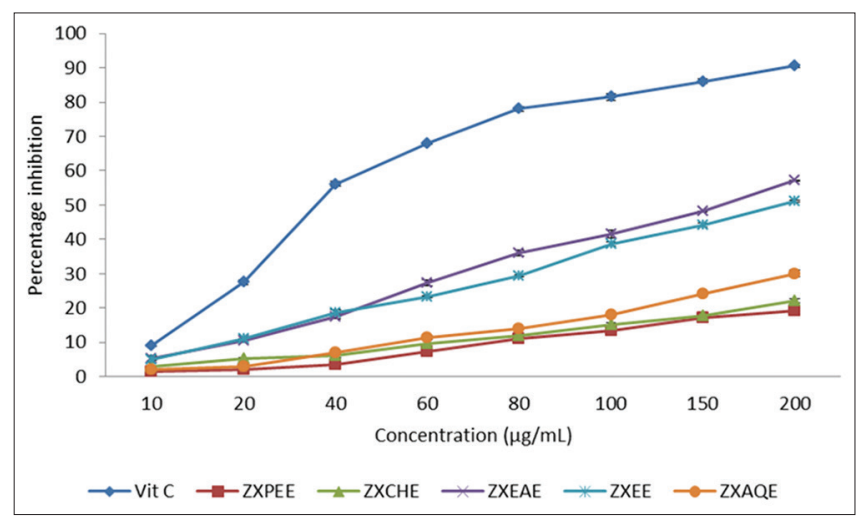

Figure 5: Percent inhibition by ZX extracts in nitric oxide radical scavenging assay. The values are represented as mean $\pm \operatorname{SEM}(n=3)$

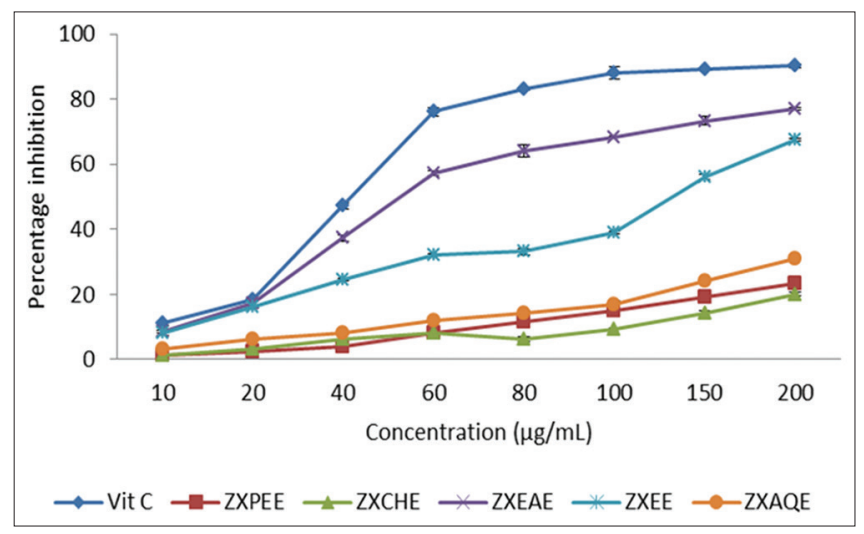

Figure 6: Percent inhibition by ZX extracts in superoxide radical scavenging assay. The values are represented as mean $\pm \operatorname{SEM}(n=3)$

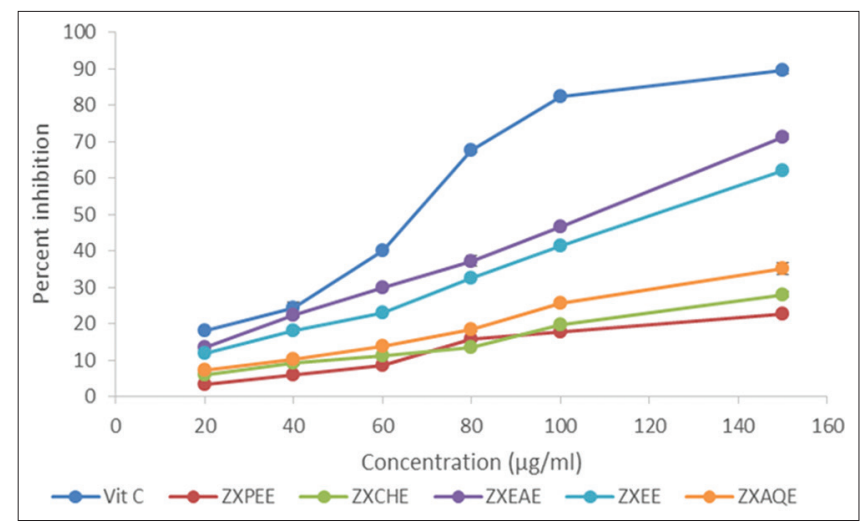

Figure 7: Percent inhibition by ZX extracts in inhibition of lipid peroxidation assay. The values are represented as mean \pm $\operatorname{SEM}(n=3)$.

situation was measured and conclusion was stated as mean \pm SEM. Further than tested ZX extracts, highest scavenging action was directed with ZXEAE subsequently ZXEE [Figure 7]. $\mathrm{IC}_{50}$ of Vitamin $\mathrm{C}$ was obtain as $59.5 \pm 0.75 \mu \mathrm{g} / \mathrm{mL}$ and manner of scavenging potential $\left(\mathrm{IC}_{50}\right)$ of Vitamin $\mathrm{C}$ and extracts was found as follows: $59.5 \pm 0.75 \mu \mathrm{g} / \mathrm{mL}$ of Vitamin $\mathrm{C}>98.6 \pm 2.05 \mu \mathrm{g} / \mathrm{mL}$ of $\mathrm{ZXEAE}>124.8 \pm 2.46 \mu \mathrm{g} / \mathrm{mL}$ of
$\mathrm{ZXEE}>304.7 \pm 3.05 \mu \mathrm{g} / \mathrm{mL}$ of $Z \mathrm{XAQE}>380.7 \pm 1.85 \mu \mathrm{g} / \mathrm{mL}$ of $\mathrm{ZXCHE}>395.6 \pm 2.96 \mu \mathrm{g} / \mathrm{mL}$ of $\mathrm{ZXPEE} . \mathrm{IC}_{50}$ of ZXEAE is 1.55 times lesser as compared to Vitamin C. At $150 \mu \mathrm{g} / \mathrm{mL}$ of concentration, the ZXEE and ZXEAE showed $62.2 \%$ and $71.5 \%$ reticence of LPO action, respectively.

\section{CONCLUSION}

Different studies reflected that the extracts of Z. xylopyrus fruits showed antioxidant activities. These effects may be due to phytoconstituents present in the extracts including flavonoids. Outcomes also proposed that antioxidant activity of $Z$. xylopyrus fruits can be utilized for hepatoprotective activity.

\section{ACKNOWLEDGMENTS}

This study was an outcome of an in-house non-financial supported study, and the authors declare no conflicts of interest.

\section{REFERENCES}

1. Gordon-Weeks AN, Snaith A, Petrinic T, Friend PJ, Burls A, Silva MA, et al. Systematic review of outcome of downstaging hepatocellular cancer before liver transplantation in patients outside the Milan criteria. $\mathrm{Br}$ J Surg 2011;98:1201-8.

2. McLaughlin JK, Lipworth L. Epidemiologic aspects of renal cell cancer. Semin Oncol 2000;27:115-23.

3. Osawa T, Uritani I, Garcia VV. Novel Natural Antioxidants for Utilization in Food and Biological Systems, Post Harvest Biochemistry of Plant FoodMaterials in the Tropics. Japan: Japan Scientific Societies Press; 1994. p. 241-51.

4. Kahkonen MP, Hopia AI, Vuorela HJ, Rauha JP, Pihlaja K, Kujala TS, et al. Antioxidant activity of plant extracts containing phenolic compounds. J Agric Food Chem 1999;47:3954-62.

5. Mansoori MH, Kaur C, Gupta MK, Vyas M, Mishra V. Ziziphus xylopyrus (Retz.) Wild: A plant of enormous biomedical potential. Int $\mathrm{J}$ Green Pharm 2018;12:S322-29.

6. Sameera NS, Mandakini BP. Investigations into the antibacterial activity of Zizyphus mauritiana lam and Zizyphus xylopyra (Retz.) willd. Int Food Res J 2015;22:849-53.

7. Singhal U, Kumar S. Antidiarrhoeal activity of fruit extracts of Zizyphus xylopyrus (Retz.) willd in rats. Int J Pharm Erudition 2011;1:57-61.

8. Olajuyigbe OO, Afolayan AJ. Phenolic content and antioxidant property of the bark extracts of Ziziphus mucronata willd. Subsp. Mucronata willd. BMC 
Complement Altern Med 2011;11:130.

9. Chouhan HS, Singh SK. Phytochemical analysis, antioxidantandanti-inflammatoryactivities of Phyllanthus simplex. J Ethnopharmacol 2011;137:1337-44.

10. Sunil C, Ignacimuthu S. In vitro and in vivo antioxidant activity of Symplocos cochinchinensis S. Moore leaves containing phenolic compounds. Food Chem Toxicol 2011;49:1604-9.

11. Gul MZ, Ahmad F, Kondapi AK, Qureshi IA, Ghazi IA. Antioxidant and antiproliferative activities of Abrus precatorius leaf extracts-an in vitro study. BMC Complement Altern Med 2013;13:53.

12. Wang H, Gao XD, Zhou GC, Cai L, Yao WB. In vitro and in vivo antioxidant activity of aqueous extract from Choerospondias axillaris fruit. Food Chem 2008;106:888-95.

13. Shirwaikarkar A, Somashekar AP. Anti-inflammatory and free radical scavenging studies of Aristyolochia bracteolate Lam. India J Pharm Sci 2003;65:67-9.
14. Shukla S, Mehta A, John J, Singh S, Mehta P, Vyas SP. Antioxidant activity and total phenolic content of ethanolic extract of Caesalpinia bonducella seeds. Food Chem Toxicol 2009;47:1848-51.

15. Singh N, Rajini PS. Free radical scavenging activity of an aqueous extract of potato peel. Food Chem 2004;85:611-6.

16. Yen GC, Hsieh CL. Antioxidant activity of extracts from du-zhong (Eucommia urmoides) towards various peroxidation models in vitro. J Agric Food Chem 1998;46:3952-7.

17. Loganayaki N, Perumal S, Sellamuthu M. Antioxidant activity and free radical scavenging capacity of phenolic extracts from Helicteres isora $\mathrm{L}$ and Ceiba pentandra $\mathrm{L}$ J Food Sci Tech 2013;50:687-95.

Source of Support: Nil. Conflict of Interest: None declared. 